\title{
Point-by-point pitvarfibrilláció-abláció új technikai aspektusai: High power - short duration abláció
}

\author{
Piros Katalin, Szegedi Nándor, Salló Zoltán, Perge Péter, Nagy Klaudia Vivien, \\ Osztheimer István, Zima Endre, Merkely Béla, Gellér László
}

\author{
Semmelweis Egyetem, Városmajori Szív- és Érgyógyászati Klinika, Budapest \\ Levelezési cím: \\ Dr. Szegedi Nándor, e-mail: nandorszegedi@gmail.com
}

Pitvarfibrilláció-abláció során a cél a pulmonalis vénák elektromos izolálása a bal pitvar üregétől. A radiofrekvenciás energia leadása során keletkező lézió részben rezisztív, részben konduktív szövetmelegítés hatására alakul ki. Az ablációs katéterek és generátorok különböző technikai fejlesztéseken estek át a homogén, tartós léziók létrehozásának elősegítése érdekében. A hatékony pitvarfibrilláció-abláció célja a széles, transzmurális, tartós léziók létrehozása. Ennek jelenlegi leghatékonyabb módja rövidebb idő alatt magas radiofrekvenciás energia leadása a szöveti felszínen. Több klinikai vizsgálat is bizonyította a technika biztonságosságát és hatásosságát.

Kulcsszavak: pitvarfibrilláció, abláció, high power - short duration

New technical aspects of point-by-point atrial fibrillation ablation: High power - short duration ablation Pulmonary vein isolation is the cornerstone of atrial fibrillation ablation. During radiofrequency applications, the lesion is created by resistive and conductive heating of the tissue. The ablation catheters and generators have undergone impressive technical developments to reach homogenous and durable lesion creation. The aim of the atrial fibrillation catheter ablation is to achieve transmural, wide, durable lesions. The most effective way to achieve this goal is to use higher radiofrequency energy for shorter duration. Multiple clinical studies have proven the safety and efficacy of this technique.

Keywords: atrial fibrillation, ablation, high power - short duration

\section{Bevezetés}

Panaszos, pitvarfibrillációval (PF) élő beteg esetében a katéterabláció a leghatékonyabb kezelési módszer a sinusritmus fenntartására (1). Megfelelő tapasztalattal rendelkező centrumokban végzett abláció az antiaritmiás gyógyszeres kezelésnél hatékonyabb (2-4). Katéterabláció során a pulmonalis vénák teljes elektromos izolálása (PVI) a cél valamilyen energia felhasználásával $(5,6)$, azonban a ritmuszavar kiújulásának aránya igen magas (7). Ennek hátterében az esetek többsé- gében a pulmonalis vénák rekonnekciója áll, amelynek oka a nem transzmurális és/vagy reverzibilis lézió (8).

\section{Történeti háttér}

Az első katéterablációt 1981-ben végezték, akkor még egyenáram felhasználásával, azonban ennek hatása nem volt megfelelően irányítható kis szöveti felület esetén. Ezt követően a radiofrekvenciás energia haszná-

A kézirat 2021. 03. 26-án érkezett a szerkesztőségbe, 2021. 05. 18-án került elfogadásra. 
latával lehetővé vált az irányított szöveti lézió létrehozása.

1998-ban Michelle Haissaguerre pitvarfibrilláló betegekben végzett elektrofiziológiai vizsgálatai során megfigyelte, hogy 94\%-ban a tüdővénákra lokalizálhatóak a ritmuszavart elindító triggerek, amelyek ablációval hatékonyan megszüntethetők (9). Kezdetben csak a triggerként kimutatott területek fokális ablációját végezték, amely részleges sikerhez vezetett. Megfigyelték, hogy ha a tüdővéna-szájadékokat elektromosan teljesen izolálják a bal pitvartól, sokkal nagyobb arányban érhető el hosszú távú ritmuszavar-mentesség $(10,11)$, így a PVI a pitvarfibrilláció-abláció sarokkövévé vált. $\mathrm{A}$ beavatkozáshoz használt elektroanatómiai térképező rendszerek fejlődésével a katéterek valós idejü mozgása, illetve a pontos bal pitvari anatómia megjeleníthetövé vált. Ez nagyban hozzájárult a point-by-point ablációs technika fejlődéséhez. Az úgynevezett single-shot eszközök bevezetésétől a beavatkozások időtartamának rövidülését, az uniform léziók létrehozását remélték, ezáltal tartósabb ritmuszavar-mentességet elérve. A beavatkozás időtartama bizonyos esetekben rövidebbnek bizonyult, de a sikerességben nem bizonyult jobbnak a point-by-point ablációhoz képest. A kontakterő-érzékelő ablációs katéterek bevezetésével pontosabb visszajelzést kapunk a szövet-katéter kapcsolatról, amely a tartós léziók képzésében kulcsfontosságú, ezáltal a hosszú távú sikerességhez is hozzájárul (12, 13). A különböző elektroanatómiai térképező rendszerek a kontakterőt is figyelembe véve pontosabb léziópredikcióra lettek képesek, jelentősen javítva a klinikai eredményességet (14). Az utóbbi időben a homogén léziók létrehozására leginkább alkalmasnak vélt magas energiájú rövid idejü (HPSD) ablációs technika biztonságosságát, hatékonyságát vizsgálják.

\section{A high power - short duration abláció fizikai alapjai}

A radiofrekvenciás energia a leggyakrabban használt energiaforrás $\mathrm{PVI}$ során. llyenkor a lézió létrejötte két lépésben zajlik: rezisztív és konduktív szövetmelegítés. A rezisztív fázis alatt a szövettel közölt elektromos áram a felületes réteg azonnali felmelegedését okozza (az elektródát körülvevő szövet, mint elektromos ellenálláson a rádiófrekvenciás váltóáram által végzett munka során keletkező hő), míg a konduktív fázis során a rezisztív fázis alatt létrejött hö terjed be a mélyebb szöveti rétegekbe. A konduktív felmelegedés egy passzív folyamat, mélysége időtartamfüggő, ugyanakkor öszszefügg a rezisztív fázis alatt kialakult hővel és az energiával is. Egy potenciális módja a közel azonos méretủ léziók létrehozásának, ha csökkentjük a konduktív fázist. Ez úgy lehetséges, ha rövid idő alatt nagyobb energiát közlünk a szövettel. Ezzel a rezisztív szövetmelegedés mértéke és az általa érintett szövet mére- te nagyobb lesz, míg a konduktív melegedés kevésbé fog szerepet kapni. A katéterstabilitás szempontjából is hatékonyabb a technika, hiszen, ha rövidebb ideig tart egy-egy applikáció, nagyobb eséllyel teremthetünk folyamatos megfelelö szövet-katéter kapcsolatot. Ezen elmélet ellenőrzésére több tanulmány is született.

A konduktív szövetmelegités a pitvari fal környezetében lévő egyéb szövetek felmelegedését és következményes károsodását is okozhatja. Hátsó fal esetében az oesophagus falának károsítása annak kifekélyesedését, akár atriooesophagealis fisztula kialakulását okozhatja $(15,16)$, továbbá előfordulhat, hogy megsértve a vagus ideget következményes gastroparesis alakul ki (17).

Bouriei és társai ex vivo vizsgálták a magas és alacsony energiájú léziók sajátosságait, sertés combizmon. Ez alapján a lézió térfogata nem változik lényegesen az ablációs energia változtatásával, viszont geometriája igen (1. ábra). A léziók szélesebbek és kevésbé mélyek voltak a high power - short duration applikációk esetén, a kisebb energiával leadott ablációkkal összehasonlítva (18). A magas energiával létrehozott lézió mélysége elegendő a transzmurális, egynemű léziók létrehozására a tüdővéna-szájadékok körül. Továbbá, a léziók nagyobb szélessége elönyösebb lehet, ha folytonos ablációs vonal létrehozására törekszünk.

\section{Szakirodalmi áttekintés}

Már 2006-ból találunk retrospektív klinikai vizsgálatot, amely a konvencionális alacsony energiájú (LP) és az új, nagy energiájú (HP) PVI-t vizsgálta. Az ablációkat hőmérsékletszabályozási módban végezték irrigációs katéterrel. Az alacsony energiájú hosszú ablációs idötartamú (LPLD) csoportban $30 \mathrm{~W}, 50^{\circ} \mathrm{C}, 120 \mathrm{sec}$, míg a magas energiájú, rövid ablációs időtartamú (HPSD) csoportban $45 \mathrm{~W}, 55{ }^{\circ} \mathrm{C}, 20 \mathrm{sec}$ volt a nominális beállitás. A HP-csoportban jelentősen több sikeres tüdövéna-izolációt regisztráltak, az ablációs idő, a beavatkozás-, a sugáridő tartamának, valamint a sugárdózis csökkenésével. Nem találtak számottevő különbséget a hosszú távú sikerességben és a szövődményrátában (19). A HPSD-csoportban az abláció során felhasznált energia jóval kevesebb volt, amelyet az LPLD-csoportban a lézió kialakulásához szükséges hosszabb applikációs idővel magyaráztak. Egy másik, 2007-ben publikált vizsgálatban, magasabb energiájú ( 50 W) abláció esetén a sikeresség növekedésével a komplikációk számának növekedését regisztrálták, amennyiben az applikáció hosszabb ideig történt egy helyen, illetve ha a magasabb energiát titrálással érték el (20). Viszont, amennyiben az energialeadás rövid ideig történt (max. $10 \mathrm{sec}$ ) egy helyen és iniciálisan magas energiát alkalmaztak, csökkent ablációs-, beavatkozásidő és sugárdózis mellett nem figyeltek meg magasabb szövődményrátát (21). Hozzátesszük, hogy ezekben a korai 


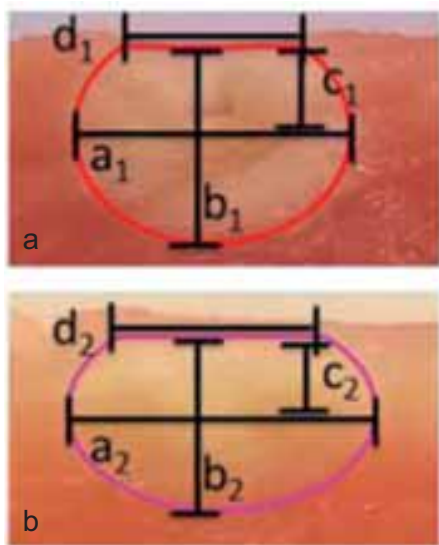

Standard $30 \mathrm{~W}, 30 \mathrm{~s}, \mathbf{1 5 - 2 0 \mathrm { g }}$ $\mathrm{a}_{1}=8,9 \pm 0,6 \mathrm{~mm} ; \mathrm{c}_{1}=2,2 \pm 0,5 \mathrm{~mm}$ $b_{1}=5,7 \pm 0,6 \mathrm{~mm} ; d_{1}=7,5 \pm 0,6 \mathrm{~mm}$ Térfogat $_{1}=271 \pm 46 \mathrm{~mm}^{3}$

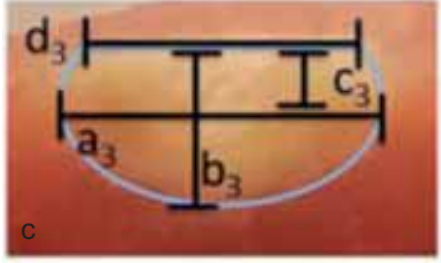

HPSD $50 \mathrm{~W}, 13 \mathrm{~s}, 15-20 \mathrm{~g}$ $\mathrm{a}_{2}=10,2 \pm 0,5 \mathrm{~mm} ; \mathrm{c}_{2}=1,0 \pm 0,4 \mathrm{~mm}$ $\mathrm{b}_{2}=4,7 \pm 0,6 \mathrm{~mm} ; \mathrm{d}_{2}=8,9 \pm 0,4 \mathrm{~mm}$ Térfogat $_{2}=274 \pm 34 \mathrm{~mm}^{3}$

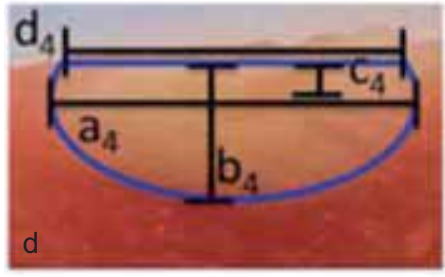

HPSD $70 \mathrm{~W}, 7 \mathrm{~s}, 15-20 \mathrm{~g}$ $\mathrm{a}_{4}=11,2 \pm 0,5 \mathrm{~mm} ; \mathrm{c}_{4}=0,6 \pm 0,2 \mathrm{~mm}$ $\mathrm{b}_{4}=3,9 \pm 0,5 \mathrm{~mm} ; \mathrm{d}_{4}=10,3 \pm 0,6 \mathrm{~mm}$ Térfogat ${ }_{4}=272 \pm 40 \mathrm{~mm}^{3}$

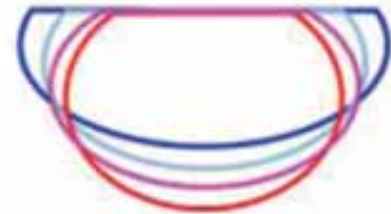

HPSD $60 \mathrm{~W}, 10 \mathrm{~s}, 15-20 \mathrm{~g}$ $a_{3}=10,4 \pm 0,6 \mathrm{~mm} ; c_{3}=0,6 \pm 0,3 \mathrm{~mm}$ $b_{3}=4,3 \pm 0,5 \mathrm{~mm} ; d_{3}=9,4 \pm 0,5 \mathrm{~mm}$ Térfogat $3=259 \pm 36 \mathrm{~mm}^{3}$

. ÁBRA. Reprezentatív keresztmetszeti képek a lézió geometriájának és térfogatának változására LPLD- és HPSD-abláció. Átlagolt mérési eredmények: a: legnagyobb átmérō, b: maximális mélység, c: legnagyobb átmérő mélysége, $d$ : felszíni átmérő. *Bourier F és társai: High-power short-duration versus standard radiofrequency ablation: Insights on lesion metrics. J Cardiovasc Electrophysiol 2018; 29(11)

vizsgálatokban még nem használtak kontakterő-érzékelő katétereket.

A magas energiájú abláció a kontakterő-érzékelő katéterek rutinszerű alkalmazásával ismét az érdeklődés középpontjába került. Amennyiben a magas energiájú (45 W) ablációt kontakterő mérésére alkalmas katéterrel végezték, szintén nem találtak különbséget a sikerességben, biztonságosságban, viszont a beavatkozás időtartama jelentősen rövidült (22). Továbbá HPSD $(50 \mathrm{~W})$ abláció során, alacsony kontakterő mellett $(<10 \mathrm{~g})$ sem találtak számottevő különbséget a sikeresség tekintetében, a korábban felsorolt beavatkozás során tapasztalt előnyök mellett (23). Egy újabb tanulmányban vizsgálták a tüdővéna-rekonnekciók arányát korábbi HPSD (45-50 W, 8-15 sec) és LPLD (20-40 W,
20-30 sec) ablációt követően, amennyiben reabláció volt indikált. Az iniciális abláció során magasabb arányban értek el first pass izolációt (ez azt jelenti, hogy az ablációs gyürủ befejezésekor a véna izolált, és további applikációra nincs szükség) HPSD esetén. A vizsgálat alapján HPSD-abláció esetén a tüdővéna-rekonnekciók aránya jelentősen kisebb volt, mint az alacsony energiájú ablációk esetében (24). Takashi és társai megfigyelése alapján magas energiájú (45-50 W) abláció során gyakoribb a hő hatására bekövetkező nyelőcsősérülés, azonban ezek nagyrészt felületes sérülések, míg kis energia esetén ritkábban előforduló, ugyanakkor mélyebb sérüléseket regisztráltak (25). A POWER-AF prospektív klinikai vizsgálat 35 és 45 W energiájú abláció rövid- és középtávú (6 hónap) eredményeit hasonlította össze. Amennyiben a beavatkozás során $38,5^{\circ} \mathrm{C}$ feletti oesophagus-hőmérsékletet észleltek 2 héten belül endoszkópos vizsgálatot végeztek. A HPSD-csoportban jelentősen rövidebb procedúraidőt regisztráltak, a tüdővéna-izolációt hamarabb érték el. Mindkét csoportban egy-egy nyelőcsősérülést regisztráltak azon a területen ahol a javasoltnál nagyobb kontakterőt használtak, illetve hosszabb időtartamú applikációkat adtak le. A magasabb energiájú abláció esetén a sérülés súlyosabb volt. A középtávú sikerességben nem találtak különbséget a két csoport között (26).

Kottmaier és társai vizsgálata alapján a HPSD (70 W) ablációk időtartama jelentősen rövidebb az LPLD-ablációhoz hasonlítva. A beavatkozások során számottevően kevesebb röntgensugárzást használtak, a szövettel közölt összenergia sokkal kevesebb volt. Ezen felül bizonyították, hogy HPSD-ablációval növelhető a hosszú távú sikeresség a szövődmények számának emelkedése nélkül (27).

Az ablációs katéterek fejlődésével lehetővé vált a katéter-szövet határon a hőmérséklet valós idejű megjelenítése, míg az új generátorok gyors teljes energialeadásra lettek alkalmasak, így lehetővé téve az igazán magas energia $(90 \mathrm{~W})$ használatát, amely szintén intenzív kutatás tárgyát képezi az utóbbi években.

Egy állatmodellben összehasonlították a HPSD (90 W, $4 \mathrm{~s}, 60^{\circ} \mathrm{C}$ ) és az LPLD (30W, $30 \mathrm{~s}$ ) ablációs módokat jobb pitvari lineáris abláció és tüdővéna-izoláció során. Mindkét módszerrel elérték a sikeres ablációs lézió létrehozásához jelenleg definiált paramétereket: hasonló kontakterőt és impedanciaesést regisztráltak. HPSD esetén az applikációs idő számottevően rövidebbnek bizonyult mind a lineáris abláció, mind a PVI esetén. A HPSD során létrehozott ablációs vonalak szélesebbek és sekélyebbek voltak, valamint sima falon történő abláció esetén, 30 napot követően is transzmurálisnak bizonyultak. A vizsgálat során nem észleltek steam pop jelenséget, perforációt vagy koagulumképződést. Ugyanakkor az LPLD-applikációk során a környező szövetek sérülését regisztrálták a hosszabb ideig tartó konduktív szövetmelegítés, és az ezáltal mélyebb léziók miatt. Ebben a vizsgálatban a HPSD-léziók ugyan 
kevésbé voltak mélyek, mint az LPLD-léziók, azonban azok a tüdővénák körüli pitvari falvastagság tekintetében transzmurális lézió létrehozásához elegendőnek bizonyultak (28).

Egy prospektív, multicentrikus klinikai vizsgálat során HPSD-módot alkalmaztak a PVI elérésére, azonban a 90 W energiájú abláció mellett az 50 W-ról történő feltitrálást is megengedte a protokoll. Összesen 78,8\%ban használtak $90 \mathrm{~W}$ energiájú ablációt a $\mathrm{PVI}$ során. Az izolált tüdővénák 5\%-ában észleltek akut rekonnekciót a beavatkozás közben. A 3 hónapos utánkövetés során a betegek 94,2\%-ában sinusritmust regisztráltak. Atriooesophagealis fisztulát, stroke-ot, TIA-t, rekeszideg-sérülést, tüdővéna-szűkületet vagy halálesetet nem észleltek. 11,5\%-ban az ablációt követő koponya-MR-vizsgálat során silent iszkémiát észleltek, amely az 1 hónapos utánkövetésnél már csak egy betegnél volt látható (29).

\section{Következtetések}

A magas energiájú rövid idejű katéterabláció a technika fejlődésével egyre nagyobb biztonsággal kivitelezhető és az állatmodellek alapján tartósabb, homogén léziók létrehozását teszi lehetővé. Hatékonyságát már klinikai vizsgálatok is igazolták, amelyek alapján a technika alkalmazása biztonságosnak tủnik, és hatékonyságában eléri, sőt bizonyos vizsgálatok eredménye alapján meg is haladja az alacsonyabb energiájú ablációét.

Az igen magas (90 W) energiával történő ablációk hatékonysága és biztonságossága tekintetében jelenleg csak kezdeti eredmények állnak rendelkezésünkre, rutin használata előtt további vizsgálatok szükségesek.

\section{Nyilatkozat}

A szerzők kijelentik, hogy az összefoglaló közlemény megírásával kapcsolatban nem áll fenn velük szemben pénzügyi vagy egyéb lényeges összeütközés, összeférhetetlenségi ok, amely befolyásolhatja a közleményben bemutatott eredményeket, az abból levont következtetéseket vagy azok értelmezését.

\section{Irodalom}

1. Hindricks G, Potpara T, Dagres N, Arbelo E, Bax JJ, et al. 2020 ESC Guidelines for the diagnosis and management of atrial fibrillation developed in collaboration with the European Association for Cardio-Thoracic Surgery (EACTS). Eur Heart J 2021; 42(5): 373498. https://doi.org/10.1093/eurheartj/ehaa612

2. Nyong J, Amit G, Adler AJ, Owolabi OO, Perel P, et al. CA. Efficacy and safety of ablation for people with non-paroxysmal atrial fibrillation. Cochrane Database Syst Rev 2016; 11(11): Cd012088. https://doi.org/10.1002/14651858.CD012088.pub2

3. Noseworthy PA, Gersh BJ, Kent DM, Piccini JP, Packer DL, et al. Atrial fibrillation ablation in practice: assessing CABANA generalizability. Eur Heart J 2019; 40(16): 1257-1264. https://doi.org/10.1093/eurheartj/ehz085

4. Marrouche NF, Brachmann J, Andresen D, Siebels J, Boersma L, Jordaens L, Merkely B, et al. Catheter Ablation for Atrial Fibrillation with Heart Failure. N Engl J Med 2018; 378(5): 417-427.

https://doi.org/10.1056/NEJMoa1707855

5. Pappone C, Augello G, Sala S, Gugliotta F, Vicedomini G, et al. A randomized trial of circumferential pulmonary vein ablation versus antiarrhythmic drug therapy in paroxysmal atrial fibrillation: the APAF Study. J Am Coll Cardiol 2006; 48(11): 2340-2347.

https://doi.org/10.1016/j.jacc.2006.08.037

6. Packer DL, Kowal RC, Wheelan KR, Irwin JM, Champagne J, et al.Cryoballoon ablation of pulmonary veins for paroxysmal atrial fibrillation: first results of the North American Arctic Front (STOP AF) pivotal trial. J Am Coll Cardiol 2013; 61(16): 1713-1723.

https://doi.org/10.1016/j.jacc. 2012.11.064

7. Kuck KH, Hoffmann BA, Ernst S, Wegscheider K, Treszl A, et al. Impact of Complete Versus Incomplete Circumferential Lines Around the Pulmonary Veins During Catheter Ablation of Paroxysmal Atrial Fibrillation: Results From the Gap-Atrial Fibrillation-German Atrial Fibrillation Competence Network 1 Trial. Circ Arrhythm Electrophysiol 2016; 9(1): e003337. https://doi.org/10.1161/circep.115.003337 8. Anter E, Contreras-Valdes FM, Shvilkin A, Tschabrunn CM, Josephson ME. Acute pulmonary vein reconnection is a predictor of atrial fibrillation recurrence following pulmonary vein isolation. J Interv Card Electrophysiol 2014; 39(3): 225-232.

https://doi.org/10.1007/s10840-013-9864-9

9. Haïssaguerre M, Jaïs P, Shah DC, Takahashi A, Hocini M, et al. Spontaneous initiation of atrial fibrillation by ectopic beats originating in the pulmonary veins. N Engl J Med 1998; 339(10): 659-666. https://doi.org/10.1056/nejm199809033391003

10. Tan ES, Mulder BA, Rienstra M, Wiesfeld ACP, Ahmed S, Zijlstra $F$, Van Gelder IC. Pulmonary vein isolation of symptomatic refractory paroxysmal and persistent atrial fibrillation: A single centre and single operator experience in the Netherlands. Neth Heart J 2009; 17(10): 366-372. https://doi.org/10.1007/BF03086286

11. Oral H, Knight BP, Tada H, Ozaydin M, Chugh A, et al. Pulmonary vein isolation for paroxysmal and persistent atrial fibrillation. Circulation 2002; 105(9): 1077-1081. https://doi.org/10.1161/hc0902.104712 12. Natale A, Reddy VY, Monir G, Wilber DJ, Lindsay BD, et al. Paroxysmal AF catheter ablation with a contact force sensing catheter: results of the prospective, multicenter SMART-AF trial. J Am Coll Cardiol 2014; 64(7): 647-656. https://doi.org/10.1016/j.jacc.2014.04.072 13. Park $\mathrm{Cl}$, Lehrmann $\mathrm{H}$, Keyl C, Weber R, Schiebeling J, et al. Mechanisms of pulmonary vein reconnection after radiofrequency ablation of atrial fibrillation: the deterministic role of contact force and interlesion distance. J Cardiovasc Electrophysiol 2014; 25(7): 701-708. https://doi.org/10.1111/jce.12396

14. Hussein A, Das M, Riva S, Morgan M, Ronayne C, et al. Use of Ablation Index-Guided Ablation Results in High Rates of Durable Pulmonary Vein Isolation and Freedom From Arrhythmia in Persistent Atrial Fibrillation Patients: The PRAISE Study Results. Circ Arrhythm Electrophysiol 2018; 11(9): e006576.

https://doi.org/10.1161/circep.118.006576

15. Cappato R, Calkins H, Chen SA, Davies W, lesaka Y, et al. Prevalence and causes of fatal outcome in catheter ablation of atrial fibrillation. J Am Coll Cardiol 2009; 53(19): 1798-1803.

https://doi.org/10.1016/j.jacc.2009.02.022

16. Szegedi N, Suhai IF, Perge P, Salló Z, Hartyánszky I, Merkely B, Gellér L. Atrio-esophageal fistula clinically presented as pericardialesophageal fistula. J Interv Card Electrophysiol 2021.

https://doi.org/10.1007/s10840-020-00922-8

17. Shah D, Dumonceau JM, Burri $H$, Sunthorn $H$, Schroft $A$, et al. Acute pyloric spasm and gastric hypomotility: an extracardiac adverse effect of percutaneous radiofrequency ablation for atrial fibrillation. J Am Coll Cardiol 2005; 46(2): 327-330. 
https://doi.org/10.1016/j.jacc.2005.04.030

18. Bourier F, Duchateau J, Vlachos K, Lam A, Martin CA, et al. High-power short-duration versus standard radiofrequency ablation: Insights on lesion metrics. J Cardiovasc Electrophysiol 2018; 29(11): 1570-1575. https://doi.org/10.1111/jce.13724

19. Nilsson B, Chen X, Pehrson S, Svendsen JH. The effectiveness of a high output/short duration radiofrequency current application technique in segmental pulmonary vein isolation for atrial fibrillation. Europace 2006; 8(11): 962-965. https://doi.org/10.1093/europace/eul100 20. Kanj MH, Wazni O, Fahmy T, Thal S, Patel D, et al. Pulmonary vein antral isolation using an open irrigation ablation catheter for the treatment of atrial fibrillation: a randomized pilot study. J Am Coll Cardiol 2007; 49(15): 1634-1641.

https://doi.org/10.1016/j.jacc.2006.12.041

21. Winkle RA, Mead RH, Engel G, Patrawala RA. Atrial fibrillation ablation: "perpetual motion" of open irrigated tip catheters at $50 \mathrm{~W}$ is safe and improves outcomes. Pacing Clin Electrophysiol 2011; 34(5): 531-539. https://doi.org/10.1111/j.1540-8159.2010.02990.x 22. Berte B, Hilfiker G, Russi I, Moccetti F, Cuculi F, et al. Pulmonary vein isolation using a higher power shorter duration CLOSE protocol with a surround flow ablation catheter. J Cardiovasc Electrophysiol 2019; 30(11): 2199-2204. https://doi.org/10.1111/jce.14122

23. Winkle RA, Moskovitz R, Hardwin Mead R, Engel G, et al. Atrial fibrillation ablation using very short duration $50 \mathrm{~W}$ ablations and contact force sensing catheters. J Interv Card Electrophysiol 2018; 52(1): 1-8. https://doi.org/10.1007/s10840-018-0322-6

24. Yavin HD, Leshem E, Shapira-Daniels A, Sroubek J, Barkagan $\mathrm{M}$, et al. Impact of High-Power Short-Duration Radiofrequency Ab- lation on Long-Term Lesion Durability for Atrial Fibrillation Ablation JACC Clin Electrophysiol 2020; 6(8): 973-985.

https://doi.org/10.1016/j.jacep.2020.04.023

25. Kaneshiro T, Kamioka M, Hijioka N, Yamada S, Yokokawa T, et al. Characteristics of Esophageal Injury in Ablation of Atrial Fibrillation Using a High-Power Short-Duration Setting. Circ Arrhythm Electrophysiol 2020; 13(10): e008602.

https://doi.org/10.1161/circep.120.008602

26. Wielandts JY, Kyriakopoulou M, Almorad A, Hilfiker G, Strisciuglio $\mathrm{T}$, et al. Prospective Randomized Evaluation of High Power During CLOSE-Guided Pulmonary Vein Isolation: The POWER-AF Study. Circ Arrhythm Electrophysiol 2021; 14(1): e009112. https://doi.org/10.1161/circep.120.009112

27. Kottmaier M, Popa M, Bourier F, Reents T, Cifuentes J, et al. Safety and outcome of very high-power short-duration ablation using $70 \mathrm{~W}$ for pulmonary vein isolation in patients with paroxysmal atrial fibrillation. Europace 2020; 22(3): 388-393.

https://doi.org/10.1093/europace/euz342

28. Barkagan M, Contreras-Valdes FM, Leshem E, Buxton AE, Nakagawa $\mathrm{H}$, et al. High-power and short-duration ablation for pulmonary vein isolation: Safety, efficacy, and long-term durability. J Cardiovasc Electrophysiol 2018; 29(9): 1287-1296.

https://doi.org/10.1111/jce.13651

29. Reddy VY, Grimaldi M, De Potter T, Vijgen JM, Bulava A, et al. Pulmonary Vein Isolation With Very High Power, Short Duration, Temperature-Controlled Lesions: The QDOT-FAST Trial. JACC Clin Electrophysiol 2019; 5(7): 778-786.

https://doi.org/10.1016/j.jacep.2019.04.009

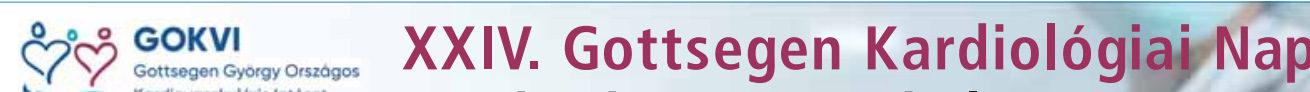 Kardio-hemato-onkológia - 2021. november 26. \\ (Danubius Hotel Helia, 1133 Budapest, Kárpát u. 62-64.) \\ A rendezvényen a részvétel ingyenes. Regisztráció a helyszínen.

